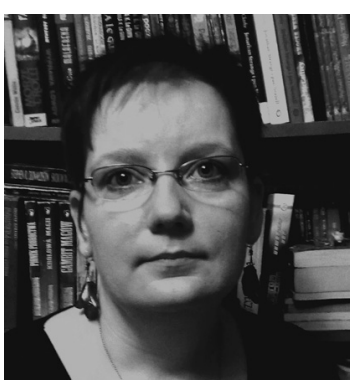

Edyta I. Rudolf

Edyta Izabela Rudolf - studiowała filologię polską na Uniwersytecie Wrocławskim, gdzie uzyskała stopień doktora (1998). Zajmuje się teorią literatury, literaturą dziecięcą w kontekście biblioterapeutycznym, literaturą fantastyczną, historią nauki i medycyny. Publikacje obejmują książkę Istoty fantastyczne we współczesnej literaturze popularnej (2000) oraz artykuły i referaty na konferencjach (Polska, Czechy), m.in.: Bestiarium w literaturze fantasy (1997), Pojęcie fantastyki. Rekonesans badawczy (1999), Bohater mityczny w literaturze fantasy (2003), Fantasy dla dzieci i młodzieży (2005), Miłość romantyczna jako figura wyobraźni (2008, redaktor). Publikowała m.in. w "Literaturze Ludowej”, "Literaturze i Kulturze Popularnej" oraz w książkach zbiorowych. Współautorka Słownika literatury popularnej $(1997,2006)$. Członek Polskiego Towarzystwa Retorycznego i Polskiego Towarzystwa Biblioterapeutycznego. 


\title{
Na straży racjonalizmu Postać lekarza w wybranych dziełach Stefana Grabińskiego
}

\author{
„Niewielu z nas jest na tyle wolnych od zaklęcia powszedniej rutyny, \\ aby odpowiedzieć na wołanie z zewnątrz"'.
}

iteratura może pełnić funkcję pomocniczego źródła w badaniach historycznych i antropologicznych, choć przyznawana jest jej ograniczona funkcja referencjalna. Analiza dzieł literackich pozwala na rekonstrukcję innej rzeczywistości, nawet jeśli powstała ona w procesie kreacji². Takie badania przyczyniają się do usystematyzowania wiedzy potocznej, jak również rekonstruują rodzimy system kultury. Szczególną przydatność wykazują utwory cieszące się czytelniczą popularnością, zawierające model kulturowej struktury ${ }^{3}$. Teksty Grabińskiego spełniają wymogi tego rodzaju badań, gdyż swego czasu były modne i wywołały szereg polemik za życia autora; przemawiały do wyobraźni współczesnych, odwoływały się do wspólnych struktur pojęciowych i wyobrażeniowych. Dzisiejsza popularność świadczy o zawartych w tych dziełach treściach zrozumiałych i akceptowanych społecznie. Ze względu na selekcję materiału analitycznego moje badania skoncentrowały się wokół postaci lekarza, co pozwoli na odtworzenie etosu tego zawodu, jak również elementów ze sfery kultury społecznej i duchowej.

Postaci lekarzy jest mało w twórczości Stefana Grabińskiego, co jest rzeczą zastanawiającą, zważywszy, że choroba, długa i śmiertelna, oraz częste wizyty w placówkach medycznych naznaczyły losy i twórczość tego odtrąconego pod koniec życia przez współczesnych pisarza. Pomijając jednak rozważania na temat wpływu choroby na pisarstwo Grabińskiego, faktem pozostaje, że wybrał rodzaj literatury dotąd słabo uprawianej w Polsce, niecenionej, rodzącej się stopniowo pod wpływem literatury zachodnioeuropejskiej. Twórczość Edgara Allana Poego, Juliusza Verne’a i George’a Wellsa wytyczyła nowe szlaki literatury, pozwala-

\footnotetext{
1 H. P. Lovecraft, Nadnaturalny horror w literaturze, tłum. A. Ledwożyn, Ł. M. Pogoda, R. Lipski, Warszawa 2008, s. 8.

2 Zob. E. Kosowska, Antropologia literatury. Teksty, konteksty, interpretacje, Katowice 2003, s. 35.

${ }^{3}$ Eadem, Postać literacka jako tekst kultury. Rekonstrukcja antropologicznego modelu szlachcianki na podstawie "Potopu" Henryka Sienkiewicza, Katowice 1990, s. 36.

${ }^{4}$ K. Czachowski, Obraz współczesnej literatury polskiej 1884-1934, t. 3: Ekspresjonizm i neorealizm, Warszawa 1936, s. 537-538. Zob. też TLSG, s. 117-118 i n.; A. Smuszkiewicz, Zaczarowana gra. Zarys dziejów polskiej fantastyki naukowej, Poznań 1982, s. 101-103, 121-124 i n.
} 
jącej, dzięki swej konwencji, na śmielsze wnioski dotyczące współczesności i przyszłości, niż miało to miejsce w literaturze realistycznej. Na gruncie amerykańskim rodziła się nowa odmiana literatury, określana mianem weird fiction, a której głównym przedstawicielem był Howard Phillips Lovecraft. Jego teoria fantastyczności, bardzo słabo lub prawie wcale nieznana w Polsce, korespondowała w znacznej mierze z poglądami twórców tekstów o tematyce fantastycznej5.

Młoda Polska odrzuciła standardy pozytywistyczne i zwróciła się ku fantastyce: „Stworzyć świat nowy, barwniejszy od rzeczywistości, a jednak rzeczywisty jako marzenie, jako wizja, jako opętanie duszy [...]"6. Jak napisał Antoni Lange we wstępie do opowiadań Ernsta T. A. Hoffmanna w 1913 roku: „fantastę rzeczywistość niezadowala [!]”7. Takie podejście, zgodne z duchem epoki, prowokowało do odmiennego, czyli nieracjonalistycznego i nieempirycznego opisywania otaczającej rzeczywistości, opierającego się raczej na wrażeniach niż doświadczeniach zmysłowych. Podkreślając ów ulotny stan poznania, Karol Irzykowski, przyjaciel Grabińskiego, zachwycając się Horlą Guy de Maupassanta, usiłował dookreślić opętanie, jakiemu się poddał autor-człowiek: „Opętał go Horla, wampir, istota wyższa [...]

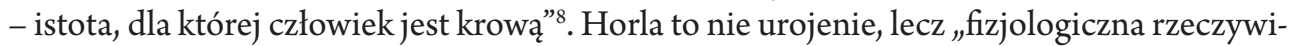
stość”, „z początku nawet śmieszna”. Ironia jednak szybko ustępuje stwierdzeniu, iż istotne jest „wrażenie” służące poznaniu Horli, a wtedy okazuje się, że świat staje się tajemniczy, obcy, cudowny ${ }^{10}$. Twórczość literacka ma na celu „zgłębienie istoty bytu, rozszerzenie sfery myśli i uczuć naszych w stosunku do niego, przybliżenie momentu rozwiązania wielkiej zagadki” ${ }^{11}$ Poznanie świata poprzez „wrażenia” nie było obce innym pisarzom, jak choćby Antoniemu Lange, który zawarł swe pomysły w zbiorze Elfryda (1895) i W czwartym wymiarze (1912), czy Franciszkowi Pik-Mirandoli, autorowi „opowiadań fantastycznych, należących do najświetniejszych nowel, jakie wydała proza neoromantyczna”" ${ }^{\prime 2}$.

Literatura fantastyczna stała się terenem dyskusji dotyczących tendencji filozoficznych epoki, wpływu techniki na ludzkie życie i na wiele innych tematów dręczących współczesnych Grabińskiemu:

Fantastyka nowoczesna jest bowiem nie kontrastem, lecz idealnym przedłużeniem współczesnego życia praktycznego i obejmuje w sobie już to antycypatywne wyczerpywanie jego możliwości rozwojowych (cudowne wynalazki), już też symboliczne pogłębianie zakresów tego życia (cudowne odkrycia geograficzne, paleontologiczne, biologiczne, metafizyczne) ${ }^{13}$.

Literatura ta zaspokajała też potrzebę silnych emocji czy niecodziennych wrażeń. Bulwersowała zakazanymi tematami (przede wszystkim seksem i przemocą, choć nie unikała też

${ }^{5}$ Marek Wilczyński wykazał niezwykłą zbieżność kreacji fantastycznych Lovecrafta i Grabińskiego (Secret Passage Through Poe: The Transatlantic Affinities of H. P. Lovecraft and Stefan Grabiński, „Studia Anglica Posnaniensia" 2008, t. 44, s. 531-538). Zob. też M. Houellebecq, H.P. Lovecraft. Przeciw światu, przeciw życiu, tłum. J. Giszczak, Warszawa 2007.

${ }^{6}$ A. Lange, E.T.A. Hoffmann, [w:] E. T. A. Hoffmann, Opowieści fantastyczne, t. 1, Warszawa [1913], s. 2.

7 Ibidem.

${ }^{8}$ K. Irzykowski, Czym jest Horla? (Rodzaj programu), [w:] idem, Nowele, Kraków 1979, s. 81.

9 Ibidem, s. 83.

10 Ibidem, s. 84.

"S. Grabiński, Zagadnienie oryginalności w twórczości literackiej, „Pamiętnik Literacki” 1925/1926, s. 1.

12 Julian Krzyżanowski pisał tak o zbiorze opowiadań Tropy wydanym w 1912 r. Zob.: idem, Dzieje literatury polskiej, Warszawa 1979, s. 496. s. 556.

${ }^{13}$ K. Irzykowski, Fantastyka, [w:] idem, Wybór pism krytycznoliterackich, oprac. W. Głowala, Wrocław 1975, 
kwestii religijnych). Zgłębiała problemy dobra i zła, ironii losu itp. W Młodej Polsce „dominuje fantastyka irracjonalna, która znalazła dogodny dla siebie grunt w społeczeństwie karmionym do tej pory hasłami płaskiego utylitaryzmu i trzeźwego, wypranego z wszelkiej metafizyki pozytywizmu” ${ }^{14}$. Jak zauważa Roger Caillois, „przerażenie, właściwe opowiadaniom fantastycznym, szerzyć się może tylko w społeczeństwach niewierzących, w których prawa przyrody uważane są za niewzruszone i niezmienne"15. Wiek kolei żelaznej i elektryczności, reagując na racjonalizm epoki, rodzi fantastykę demonologiczną, asymilującą zdobycze nowoczesnej psychiatrii i psychologii, spirytyzmu i mediumizmu.

Choroby psychiczne traktowano jako nawiedzenie przez złego demona lub opętanie przez ducha i wiązano z życiem pozagrobowym. Wiek XIX postawił chorobie strażnika lekarza, badacza, eksperymentatora. To już nie Molierowski hochsztapler, gość salonów, opiekun wybranych, lecz zawodowiec z misją walki z chorobą w ramach zorganizowanej służby zdrowia.

\section{Etos lekarza na przełomie XIX i XX wieku}

Wiek XIX to okres kształtowania się nowożytnej medycyny, a co za tym idzie, nowego podejścia do zawodu lekarza, stającego się profesją zaufania społecznego. Zasięg działalności lekarskiej jest coraz szerszy, coraz więcej ludzi objętych zostaje profesjonalną opieką medyczną. Choć etyka lekarska ma swe źródła w zawodzie i sięga starożytności, to jednak wiek XIX postawił przed medycyną nowe zadania: rozwój klinik, przychodni, pojawienie się stanowisk lekarzy zakładowych, placówek doraźnej opieki zdrowotnej itp. Zmieniła się również jurysdykcja obejmująca coraz większym zasięgiem działalność zawodową lekarzy.

Druga połowa XIX wieku na terenach polskich to czas dyskusji nad nowoczesną deontologią, spełniającą wymogi prawa i ogólnie rozumianej etyki. Jak trudne było to zadanie, świadczą słowa Władysława Biegańskiego, profesora medycyny i etyki, który tak pisał w swych Myślach i aforyzmach z 1899 roku:

Niektórzy lekarze próbują ująć etykę lekarską w pewne przepisy, te pozostaną na zawsze martwą literą, jeśli nie będą wypływały z własnego poczucia lekarzy, z ideałów, jakie powinny przyświecać naszej działalności, gdyż poziom etyki nie podnosi się przez moralizatorstwo, lecz wychowanie w całokształcie uwrażliwienia etycznego osobowości lekarza, analizę własnego, przemyślnego, a nie sterowanego zakazami postępowania ${ }^{16}$.

Od czasów starożytnych kształtował się wizerunek lekarza ${ }^{17}$, a w jego centrum najważniejsza norma - uznanie dobra chorego jako najważniejszego nakazu. Ponadto niezbywalnymi

14 A. Smuszkiewicz, op. cit., s. 125.

15 R. Caillois, Od baśni do „science fiction”, tłum. J. Lisowski, [w:] idem, Odpowiedzialność i styl, Warszawa 1967, s. 50

${ }^{16}$ W. Biegański, Myśli i aforyzmy o etyce lekarskiej, Warszawa 1899, s. 21.

17 W. Szumowski, Historia medycyny filozoficznie ujęta, Warszawa 1994, s. 79. 


\section{Ilustracja do noweli}

Engramy Szatery,

„Naokoło Świata" 1926, nr 28,

rys. J. Kożuchowski

\section{0}

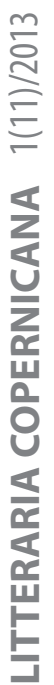

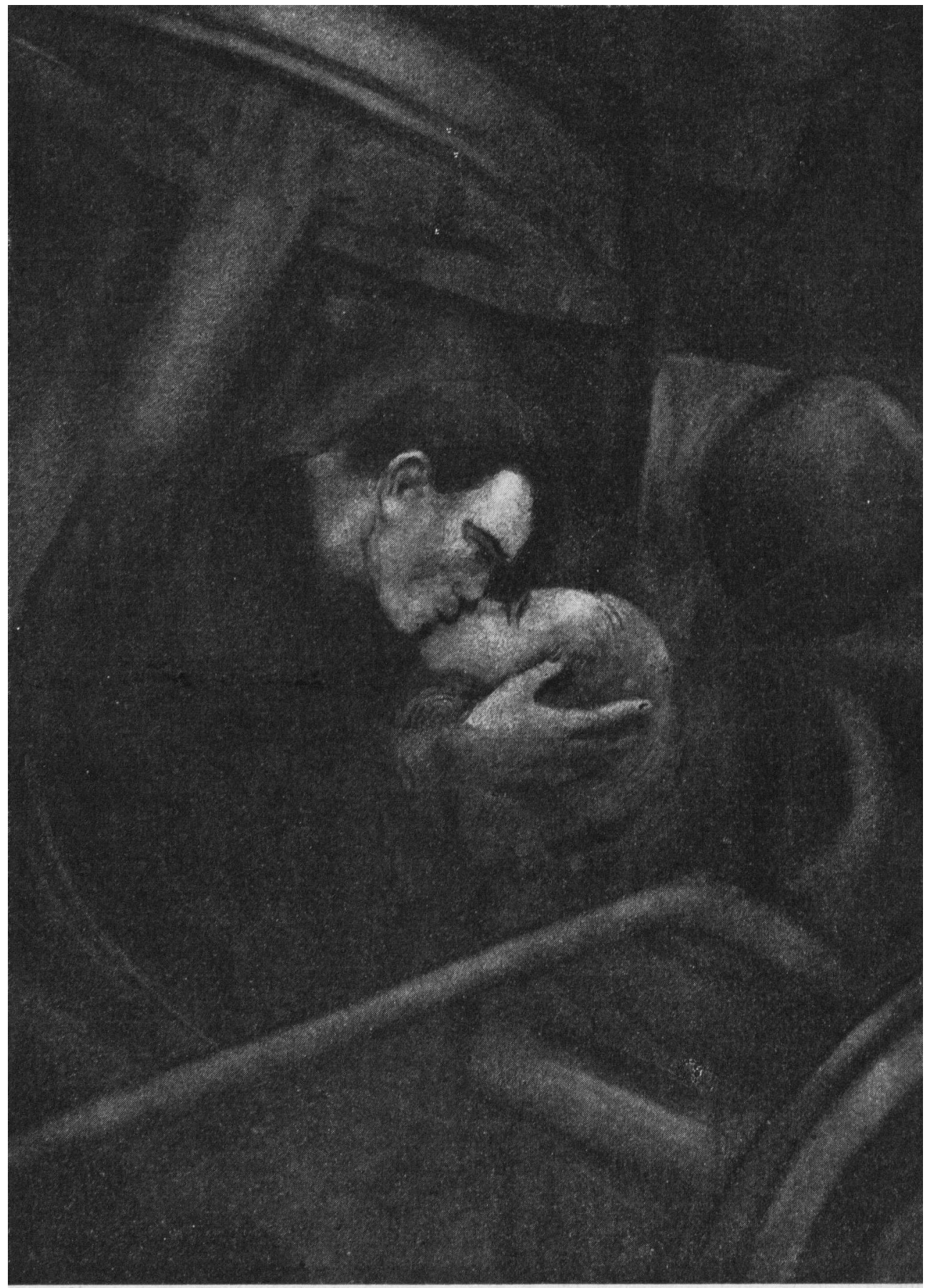

... Szatera pochylit się ku tej umęczonej głowie, uziq jq ostrożnie wo obie dtrnie niby relikwię $i$ przycisnat usta do jej ust zbielałych... 
cechami miało być stałe zgłębianie wiedzy, odpowiedni wygląd zewnętrzny, a nade wszystko wysokie morale przejawiające się w posiadaniu cech charakteru, takich jak:

miłość afirmująca godność każdej osoby ludzkiej, szacunek dla życia, zdrowia i cierpienia, dobroć, rzetelność, współczucie, wrażliwość, altruizm, gotowość do niesienia pomocy potrzebującym, samodzielność myślenia i działania, odwaga, poświęcenie, powściągliwość, skromność, ostrożność w doborze słów, pogodny nastrój, umiarkowany optymizm, życzliwość, troskliwość, sumienność, stanowczość, cierpliwość, odpowiedzialność, bezinteresowność, przyzwoitość, powaga, godność osobista, wyrozumiałość, obowiązkowość, pracowitość, wstrzemięźliwość, prawdomówność, hart ducha, takt, czy dyskrecja ${ }^{18}$.

Na ziemiach polskich pierwszy kodeks deontologiczny powstaje w zaborze austriackim; wydano go w 1876 roku pt. Uchwaly Towarzystwa Lekarzy galicyjskich $w$ przedmiocie obowiązków lekarzy względem swoich kolegów i zawodu lekarskiego w ogóle. Reguły deontologii zrewolucjonizowały artykuły kodeksu Warszawskiego Towarzystwa Lekarskiego - Zasady obowiązków i praw lekarzy, które zostały ogłoszone drukiem w 1884 roku w „Pamiętniku Towarzystwa Lekarskiego Warszawskiego”. Pojawiały się prace dotyczące deontologii, wykładające zasady postępowania lekarza nie tylko wobec chorego, ale również wobec społeczeństwa i kraju, będące równocześnie głosami żywej dyskusji toczącej się w owym czasie: Emanuela Sonnenberga Dyskrecya lekarska ze stanowiska prawnego i etycznego (1895), Leopolda Kosińskiego Projekt etyki lekarskiej (1897), Szczepana Mikołajewskiego Projekt deontologii lekarskiej (1907). Przełomem stał się X Zjazd Lekarzy i Przyrodników Polskich we Lwowie w 1907 roku, na którym zaakceptowano i ogłoszono pierwszy wspólny dla lekarzy polskich wszystkich trzech zaborów Kodeks Deontologii Polskiej, będący później podstawą do formułowania zasad etyki lekarskiej w niepodległej Polsce. Na uwagę zasługują też prace o charakterze podręczników akademickich, np. Teodora Heimana Etyka lekarska i obowiązki lekarza (deontologia) (1917). Reasumując, można powiedzieć, że Grabiński był za swego życia świadkiem głębokich przemian w środowisku lekarskim i żywiołowych dyskusji dotyczących norm i powinności zawodu lekarskiego oraz regulacji między lekarzem a pacjentem lub społeczeństwem. Nowe warunki pracy, obejmujące wielogodzinne dyżury w szpitalach, niskie zarobki ogółu lekarzy, wzrastająca konkurencja, jak również obowiązek - początkowo etyczny, a następnie prawny - opieki nad chorym ubogim, opieki nad chorym w czasie epidemii i wojny oraz chorym mogącym przyczynić się do śmierci lekarza - to najistotniejsze kwestie. Jeszcze w drugiej połowie XIX wieku stosunek do zawodów medycznych był pozytywny, lekarz cieszył się przeważnie szacunkiem danej społeczności. Zachodzące zmiany dotknęły i tę profesję, a obok pozytywnych wzorców zaczęły pojawiać się głosy krytyczne w stosunku do uczniów Asklepiosa, obecne również w literaturze, jak np. u Stefana Żeromskiego w Promieniu (1897) czy Michała Choromańskiego w Zazdrości i medycynie (1932). Niewątpliwie Grabiński był świadom owej rewolucji, a nawet do pewnego stopnia, jako przewlekle i śmiertelnie chory, stał się jej uczestnikiem. Krytyczny stosunek do leka-

18 J. Gilewska-Dubis, Etos zawodu lekarza w relacji z pacjentem w średniowiecznej medycynie europejskiej, [w:] Relacje lekarz-pacjent w aspekcie społecznym, historycznym i kulturowym, red. B. Płonka-Syroka, "Studia z Dziejów Kultury Medycznej”, t. 10, Wrocław 2005, s. 85. Zob. też: T. Brzeziński, Tradycyjne zasady deontologii lekarskiej, [w:] Etyka i deontologia lekarska, red. T. Kielanowski, Warszawa 1985, s. 25-46. 
rzy ujawniał się nie tylko w nowelach, w których przedstawiciele medycyny występowali jako orzecznicy śmierci, o czym szerzej w dalszej części artykułu. Wątpliwości wzbudzała etyka zawodowa niektórych z nich, jak chociażby w opowiadaniu Płomienne gody (1922), gdzie lekarz psychiatra uwodzi pacjentkę, wmawiając, że jest jej mężem. Doprowadza to do tragedii, śmierci z ręki załamanego męża. W licznych opowiadaniach podkreślona zostaje bezsilność ludzi medycyny wobec rozlicznych schorzeń.

Kiedy w świecie kultury dominowało hasło „przewartościowania wszystkich wartości”, głoszone przez Friedricha Nietzschego, a w świecie nauk przyrodniczo-technicznych trwał czas odkryć, Grabińskiego czekał jedynie zawód. Choć w 1882 roku Robert Koch odkrył prątka gruźlicy, a od 1921 roku zaczęto stosować szczepionkę przeciwgruźliczą $(B C G)^{19}$, to prawdziwy ratunek przyniosła dopiero streptomycyna wynaleziona w 1943 roku, a wprowadzona do powszechnego użytku od roku 1948. Grabiński, wraz z całą rzeszą chorych na tuberkulozę, pozostał poza strefą odkryć mogących przynieść ratunek. Skazany więc został na leczenie ówczesnymi metodami, a co za tym idzie, na długą i bolesną agonię ${ }^{20}$. $Z$ pewnością też doświadczył różnej jakości usług medycznych, a stopniowe ubożenie nie przyczyniało się do ich polepszenia ${ }^{21}$. Cień grozy i niesamowitości był więc dla Grabińskiego bytem realnym, choć niewidzialnym, należącym do rzeczywistości.

\section{Lekarz i ostateczna diagnoza}

Przez całe swe życie otoczony przez lekarzy, zapewne różnych - dobrych i złych, kompetentnych i nieuków, Grabiński musiał w jakiś sposób afirmować te doświadczenia i z pewnością wplatał je w artystyczną wizję. Brak ich obecności do pewnego stopnia tłumaczą wspomnienia Jerzego Kolankowskiego, syna przyjaciela Grabińskiego, a później znanego lekarza, który opisywał pisarza jako słabego zdrowia:

Mówiąc ściślej - słaby na płuca. Słowa gruźlica nikt nie wypowiadał, jedynie może lekarz i to niezmiernie oględnie (ta nieuleczalna wówczas choroba zabrała mu ojca i dwie siostry). Nie było to bowiem jeszcze słowo groźne i złowróżbne, ale po prostu „skłonność” do przeziębień, kaszlu, chrypki, nierzadkiej zresztą wśród nauczycieli. Nic groźnego jednym słowem (że to eufemizm, pisarz zdawał sobie chyba sprawę) $[\ldots]^{22}$.

Można powiedzieć, iż pisarz bał się diagnozy ostatecznej, dookreślenia jego stanu, a tym samym przeniesienia jego bytu w strefę umierania, powolnej wegetacji zmierzającej ku końcowi i to w samym rozkwicie życia. Ów strach i realna bliskość śmierci przesunęła prawdopo-

\footnotetext{
19 Szczepionka przeciwgruźlicza została opracowana przez Alberta Calmetta i Camilla Guérina (BCG), a pierwsze szczepienie nastąpiło w 1921 roku przez doustne podanie szczepionki noworodkowi, którego matka zmarła na gruźlicę. Zob. Historia medycyny, red. T. Brzeziński, Warszawa 2000, s. 433.

20 Końcowy akt trwał ok. 5 lat.

21 O zmaganiach Grabińskiego z chorobą pisał m.in. znany mu osobiście Jerzy Eugeniusz Płomieński, Suweren polskiej fantastyki literackiej: Stefan Grabiński, [w:] idem, Twórcy bez masek. Wspomnienia literackie, Warszawa 1956, s. 101-149.

22 J. Kolankowski, O Stefanie Grabińskim, oprac. T. Pudłocki, „Rocznik Przemyski” 2005, t. 41, z. 3, „Literatura i Język", s. 89.
} 
dobnie lekarzy z symbolicznej strefy strażników życia w strefę śmierci, bo to właśnie lekarz anonsuje jej nadejście.

Jeszcze na początku XIX wieku, aby otrzymać pozwolenie na pogrzeb, wystarczyło poświadczenie śmierci człowieka przez znające go otoczenie. Na takiej tylko podstawie rejestrowano zgon. We Francji Kodeks cywilny z 1804 roku wprowadził do prawa pierwsze gwarancje przeciwko pomyłkom prowadzącym do grzebania żywych jeszcze ludzi. Wolno było wydawać pozwolenie na pogrzeb po dwudziestu czterech godzinach od zgonu. Następnie wymagano, by zgon został stwierdzony przez lekarza. Na ziemiach polskich sprawa była bardziej skomplikowana. Poszczególne rozporządzenia zależały od zaborców i różniły się między sobą. Po odzyskaniu niepodległości zaczyna się formułowanie wymaganych ustaw. Orzeczenie śmierci w pełnym brzmieniu definiuje Ustawa z dnia 17 marca 1932 roku o chowaniu zmarlych i stwierdzaniu przyczyn zgonu (Dz.U.R.P. Nr 35. poz. 359), mówiąca, że śmierć może orzec jedynie lekarz leczący chorego bądź lekarz urzędowy. Śmierć stała się sprawą specjalistów i nastąpił jej stopniowy marsz ku instytucjonalizacji.

Proces ten odbywał się na oczach Grabińskiego, a w jego opowiadaniach lekarze stają się zimną wyrocznią końca. To nie ludzie, lecz obojętne instytucje, znak nowych czasów i odpersonalizowanej śmierci. Początek owych zmian zauważalny był znacznie wcześniej, kiedy to obecność lekarza stała się obowiązkowa przy pojedynkach. Ślad tego można odnaleźć w powieści Cień Bafometa, w której lekarz towarzyszy pojedynkowi Pomiana i Pradery. W nowelach Sygnały, Nocleg czy Projekcje śmierć stwierdza już urzędowa komisja. Życie bohaterów i niezwykłe okoliczności śmierci potwierdzone zostają lakonicznym sformułowaniem: „Obecny lekarz stwierdził śmierć zaszłą przynajmniej dziesięć dni temu. Spisano protokół i pochowano na miejscu zwłoki, rezygnując z obdukcji z powodu silnie posuniętego zepsucia” (NO, s. 53). W Pojednaniu lekarze mają określić śmierć małżeństwa zmarłego w niezwykłych okolicznościach: „Umarli młodzi i piękni tej samej nocy. Lekarze stwierdzili śmierć naturalną wskutek udaru serc: samobójstwo było wykluczone"23. Narrator, zdystansowany od opisywanych zdarzeń, ukazuje bezradność medycyny klinicznej wobec wielkiej tajemnicy. Jedno zdanie świadczące o bezsilności współczesnej nauki zamykało niezwykłą historię związku Henryka i Stanisławy Łumińskich, którzy ponownie odnaleźli swe szczęście małżeńskie w krainie snu, przygody zakończonej śmiercią. Przed podobnym, niemożliwym do wykonania zadaniem stanęła komisja w opowiadaniu Projekcje, gdzie szczątki protagonisty odnaleziono dopiero po roku w ruinach klasztoru Trapistek, a jedynym źródłem wyjaśnienia zdarzeń był pamiętnik denata. Przybyła komisja stwierdziła, że śmierć architekta była wynikiem nieszczęśliwego wypadku, gdyż usiłując wydostać się z lochów (do których nie wiadomo jak się dostał), włożył on głowę w dziurę w kratach i przebił sobie tchawicę. Historię opisaną w pamiętniku złożono na karb choroby i rozstroju nerwowego.

Komisja postrzegana bywa przez bohaterów w nie do końca pozytywnym świetle. W opowiadaniu Nocleg protagonista tak ją opisuje: „, [... ] do środka weszło paru mężczyzn: trzech chłopów z wójtem na czele, żandarm, jakieś chuderlawe indywiduum o wyglądzie pisarza grodzkiego i dwóch gentlemanów. Towarzystwo miało postawę uroczystą, urzędową" (NO, s. 84). Obecny lekarz w komisji wyraził dezaprobatę na wieść, że bohater spędził noc w pomieszczeniu razem z trupem, gdy jednak zobaczył nieboszczyka, zbladł. Następnie przeprowadził obdukcję: „Lekarz otworzył duże, orzechowe puzdro i zaczął dobywać zeń

${ }^{23}$ S. Grabiński, Pojednanie, [w:] idem, Namiętność (L’Appassionata). Opowieść wenecka, Warszawa [1930], s. 138 . 


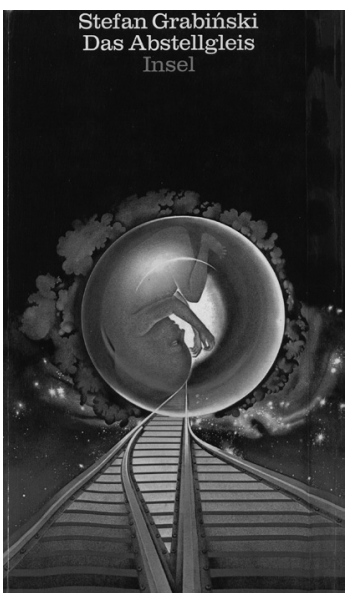

S. Grabiński, Das Abstellgleis: unheimliche Geschichten, Insel-Verlag, Frankfurt am Main 1971 przybory do obdukcji. Połyskiwały pod światło zimne ostrza lancetów, rozlegał się metaliczny dźwięk rozkładanych w porządku nożów i pincet” (NO, s. 85). Widoczny jest w tej scenie profesjonalizm lekarza, jego opanowanie świadczące też o pewnej rutynie wynikającej z zawodowych zadań. Zarazem bladość twarzy na widok nieboszczyka sygnalizuje, że nie jest pozbawiony wrażliwości.

Bezradność medycyny klinicznej widoczna jest w Salamandrze, gdzie na jedną z bohaterek rzucono śmiertelny czar. Najpierw na jej ciele pojawily się tajemnicze guzy, z których oprócz ropy wypływały kawałki ziemi i szkła, szpilki, drewienka, czarne nici. Lekarze byli bezradni, wręcz zdumieni tak tajemniczą dolegliwością. Wtedy też poproszono o pomoc Andrzeja Wierusza, tajemniczego człowieka interesującego się mistycyzmem i magią. Akt uzdrowienia bohaterki przez „maga” za pomocą tajemniczych obrzędów i środków można potraktować jako krytykę ówczesnej medycyny klinicznej. Lekarz, dr Biegański, staje się pomocny dopiero $\mathrm{w}$ okresie rekonwalescencji głównego bohatera i narratora zarazem. Zostaje sprowadzony do roli pielęgniarza, gdyż czuwał nad pacjentem, karmił go i poił, jednak nie był w stanie określić choroby, która bohaterowi odebrała przytomność na cały miesiąc. Biegański stara się zracjonalizować całe zdarzenie, znaleźć „naukowe” wyjaśnienie i z czasem uświadamia sobie klęskę takiego sposobu myślenia.

W każdym z przytoczonych opowiadań lekarze dążyli do ustalenia diagnozy i zracjonalizowania śmierci, sprowadzali ją do sfery nauki i ignorowali niepokojące sygnały świadczące o niezwykłości okoliczności jej towarzyszących, ale mogących naruszyć zdroworozsądkową wizję świata. Nie dopuścili Tajemnicy do głosu, ukryli ją pod naukowym faktem, pozostali niewzruszeni. Można jedynie postawić pytanie: czy za takim sposobem działania kryje się rutyna, ignorancja czy strach przed nieznanym?

\section{Ulecz duszę, ulecz ciało}

Lęk przed śmiercią i niepogodzenie się z faktem biologicznym legły u podstaw artystycznej wizji pisarza, co przyczyniło się do określenia literatury fantastycznej mianem psychofantazji bądź metafantastyki, rozumianej jako wytwór procesów umysłowych, mogących znaleźć naukowe wyjaśnienie we współczesnej psychologii ${ }^{24}$. Zwrot ku innemu światu, poszukiwanie kontaktu z inną sferą życia wydają się zrozumiałe wobec choroby predestynującej ku takiemu właśnie myśleniu. Gruźlica bowiem przyczyniła się do zbudowania koncepcji, że ludzie osiągają wyższą świadomość w kontakcie ze śmiercią, zmienia się ich umysł, otwierając na nowe sfery psychicznych doświadczeń ${ }^{25}$.

Początku zachwytu nad współczesną psychopatologią można upatrywać w wykładach profesora uniwersytetu w Turynie, Cezara Lombroso (1836-1909), który pierwszy wskazał na istnienie współczynnika psychopatycznego w jednostkach twórczo uzdolnionych. Jego prace wyrosły w dużej mierze z badań fizjologów, którym udało się już odróżnić w mózgu ośrodki ruchowe od ośrodków inteligencji. Zanim to jednak nastąpiło, świat nauki

${ }^{24}$ S. Grabiński, O twórczości fantastycznej. Jej geneza i źródła. (Wstęp do szkicu), „Lwowskie Wiadomości Muzyczne i Literackie" 1928, nr 10, s. 1.

${ }^{25}$ Poglądy Grabińskiego były zgodne również z literackimi refleksjami dotyczącymi gruźlicy jako tej, która osłabia ciało, ale uduchowia osobowość i pogłębia świadomość: S. Sontag, Choroba jako metafora. AIDS i jego metafory, tłum. J. Anders, Warszawa 1999, s. 13-23, 26-33 i n. 
podbiła tzw. frenologia, zakładająca, iż w mózgu znajdują się specjalne ośrodki anatomiczne dla różnych władz psychicznych. Twórcą tej hipotezy był wiedeński lekarz Franciszek Gall (1758-1828) ${ }^{26}$. Powstanie placówek specjalistycznych, w tym szpitali dla obłąkanych, przyczyniło się do naukowego badania osób z zaburzeniami psychicznymi. Jako pierwszy wprowadził do psychiatrii klinicznej anatomię patologiczną Wilhelm Griesinger (1817-1868), a z analizy psychozy zasłynął wiedeński klinicysta Teodor Meynert (1833-1892). Z kolei Richard Krafft-Ebing (1840-1903) zajmował się psychopatologią życia seksualnego i kryminalistyką. Na tych podstawach, jak już zostało wspomniane, wyrosła praca Lombrosa Geniusz i obłąkanie (1864), przetłumaczona na język polski w 1887 roku, analizująca związki między niepoślednimi zdolnościami twórczymi a dewiacjami osobowości. Psychiatra poddał oglądowi życie i zachowania postaci historycznych: Monteskiusza, Napoleona, Schillera i wielu innych.

Wątek ten podjęła psychiatria i psychopatologia lat 20. i 30. XX wieku, wykazując, jak niewielka granica dzieli normę psychiczną od anomalii. Temat ten stał się szczególnie atrakcyjny dla twórców tamtej epoki, przyczyniając się do powstania specyficznej „mody na szaleństwo". Autor Demona ruchu nie był wolny od tych fascynacji:

Dla Grabińskiego owa „ciemna strona” ludzkiej psychiki i życia, zjawiska szaleństwa i obłędu, rozdwojenia osobowości, sobowtórstwa, somnambulizmu, katalepsji, przedstawiały szczególny i dodatkowy urok jako jeszcze jedno świadectwo zdające się przemawiać na rzecz immanentnej dziwności i tajemniczości świata, jego zdumiewającego polimorfizmu. Owe anomalie psychiczne, odchylenia i głębokie dewiacje to według Grabińskiego jakby protuberancje życia, wyrzucone z jego glębin nadmierną prężnością soków; w nich to wygaduje się jak gdyby pandemonium bytu, a stopniowe pogrążanie się w mroki obłędu to niekiedy, wbrew pozorom, powolne wstępowanie w świetlisty krąg jasnowidzenia [PD, s. 229-230].

Jednym z zagrożeń dla zdrowia psychicznego i fizycznego, konkretnie dla życia mężczyzny, może być żywioł płci, ucieleśniony w kobiecie symbolizującej siły destrukcji i rozkładu. Bohater opowiadania $W$ domu Sary, Kazimierz Stosławski, ulegając czarowi demonicznej kusicielki - Sary Bragi, zaczyna podupadać na zdrowiu. Zauważa to jego przyjaciel lekarz i postanawia mu pomóc. Najpierw wchodzi w rolę detektywa, odkrywając, że Sara b y ł a podopieczną jego mistrza, profesora neurologii, Franciszka Żmudy. Przyczyną jej terapii psychiatrycznej były skłonności psychopatyczne na tle seksualnym. Lekarz rozpoczął obserwację Sary i jej kochanków i doszedł do wniosku, że kobieta dosłownie pochłania mężczyzn i tym samym zachowuje wieczną młodość. Narrator z przerażeniem, a zarazem naukową fascynacją obserwował zmiany zachodzące w przyjacielu: „Był [Stosławski] przejrzysty $[. .$.$] . Nie dowierzając wzrokowi dotknąłem go: ręka natrafiła na coś ustępliwego jak$ gęsta ciecz" (NO, s. 284). Po początkowym szoku postanawia zemścić się za przyjaciela. Choć nie potrafił uleczyć ani ciała, ani duszy, to starał się zniszczyć zło - Sarę.

W Wyspie Itongo lekarze psychiatrzy, Będziński i Przysłucki, opiekują się fenomenalnym medium, Janem Gniewoszem. Będziński w wyniku własnych badań i eksperymentów sformulował teorię łączącą psychiatrię z metapsychiką, wykazując, „że często objawy schorzeń duchowych i fenomeny metapsychiczne przenikają się nawzajem jak dwie siostrzane

\footnotetext{
26 W. Szumowski, op. cit., s. 576.
} 
Ilustracja do noweli

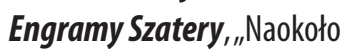

Świata" 1926, nr 28,

rys. J. Kożuchowski

\section{6}

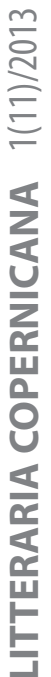

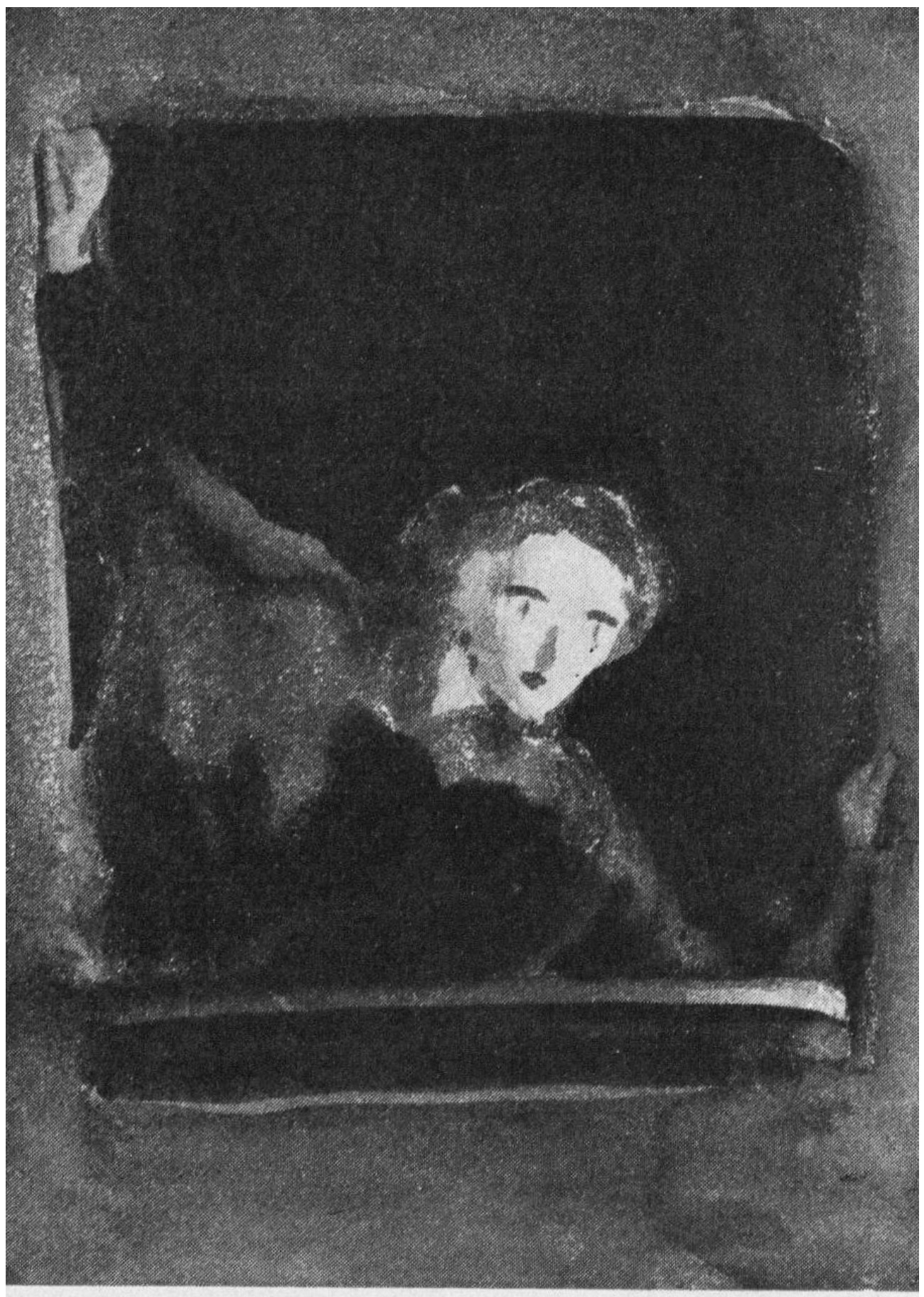

.. Teraz kobieta ta powtarzała swq tragicznq role... 
strugi wytrysłe z jednego źródła”27. Będziński reprezentował stanowisko przyrodnicze, poszukując rozwiązań naturalnych, fizycznych. Gdy tymczasem jego współpracownik doszukiwał się wyjaśnienia tajemniczych zjawisk w spirytyzmie, a nawet okultyzmie. Obaj uczeni, reprezentujący odmienne poglądy na naturę zjawiska wytwarzanego przez medium, wpisują się w XIX-wieczny spór toczący się między „somatykami” a „psychikami”. Dla tych pierwszych istota choroby psychicznej polegała na zmianach w mózgu, a objawy psychopatologiczne były wyrazem jego anatomicznego stanu. „Psychicy” natomiast sądzili, że choroba tkwi w duszy, która jest różna od ciała, a zmiany anatomiczne w mózgu występują jako następstwo choroby ${ }^{28}$. Grabiński zaproponował jednak swoje rozwiązanie, a element fantastyczny pozwolił mu na wyjaskrawienie znamion zjawiska, którego uczeni bohaterowie byli świadkami. Nie rozstrzygnął sporu na niczyją korzyść - zachowania bohaterów, ich stany psychiczne i objawy chorobowe wskazują na łączność pomiędzy duszą a ciałem oraz ich wzajemną złożoność, tym trudniejszą do zanalizowania w kontekście realnej w świecie przedstawionym ingerencji sił nadnaturalnych. Bezradność lekarzy wynika nie tylko $\mathrm{z}$ braku zrozumienia samej natury zjawiska, ale również z faktu obrony świadomości przed przyjęciem istnienia innych, obcych sił wpływających nie tylko na psychikę, ale również na stan fizyczny organizmu ludzkiego. Leczenie zatem opierałoby się na rozpoznaniu tych sił, na analizie sposobu ich wpływu na ludzką kondycję psychiczną i fizyczną, a następnie opracowaniu kuracji przeciwdziałającej dalszym zmianom, jak też niwelowaniu już dokonanych szkód. Tylko w opowiadaniu $W$ domu Sary lekarz odnosi częściowe zwycięstwo nad demonicznymi mocami, tracąc przy tym pacjenta.

\section{Na straży szaleństwa}

Grabińskiemu nie była obca dyskusja dotycząca związków między geniuszem a obłąkaniem rozpoczęta przez Lombrosa, trwająca zresztą do ostatnich dni pisarza. Według Artura Hutnikiewicza pisarz interesował się psychiatrią ze względu na własne problemy z psychiką (por. TLSG, s. 214) - Grabiński doświadczył na sobie samym ciemnej strony swojej osobowości. Mógł do woli analizować tajniki swej duszy i konfrontować to z dyskusjami dotyczącymi obłąkanych geniuszy. Ponadto obłęd otwierał tematykę wpisującą się w jego program literacki, odpowiadał postulatowi oryginalności. W owym czasie w sposób nowatorski, a dziś już całkowicie „ograny”, wyzyskał przestrzeń szpitala dla psychicznie chorych.

W noweli Gebrowie główny bohater, doktor Ludzimirski, dyrektor szpitala dla obłąkanych, od piętnastu lat troszczył się o swoich podopiecznych. Widział w nich nie przejaw psychofizycznego schorzenia, lecz „egzotyczne kwiaty wyrosłe z podłoża chorych mózgów” ${ }^{\prime 2}$. W terapii chorych zastosował nowoczesną francuską metodę, polegającą na daniu swobody poruszania się chorym na terenie zakładu. Terapia ta ma swe źródła w epoce Oświecenia. Wcześniej uważano, że psychicznie chorzy są opętani przez diabła, dlatego nieszczęśników izolowano, tzn. umieszczano w piwnicy, lochu itp., niejednokrotnie trzymając na łańcuchu, we własnych odchodach. Początki psychiatrii łączy się z rewolucją francuską,

27 S. Grabiński, Wyspa Itongo. Powieść, Warszawa 1936, s. 40.

28 W. Szumowski, op. cit., s. 637.

29 S. Grabiński, Gebrowie, [w:] idem, Księga ognia. Nowele, Łódź 1922, s. 85. 
kiedy powstała idea „uwolnienia” szaleńców. Dotknięci upośledzeniem zamykani byli dotąd w więzieniach wraz z innymi przestępcami. Często dochodziło do bójek kończących się śmiercią chorych. W 1793 roku francuski lekarz Filip Pinel (1745-1826) otrzymał zgodę na zdjęcie łańcuchów z obłąkanych. Próba powiodła się, ponieważ chorzy przestali być agresywni i się uspokoili ${ }^{30}$. Uczeń Pinela, Jean Étienne Esquirol (1772-1840), został dyrektorem zakładu dla obłąkanych w Charenton pod Paryżem, a dziś uznaje się go za twórcę nowożytnego sposobu leczenia umysłowo chorych.

Idąc zapewne śladem swych wielkich poprzedników, Ludzimirski stosuje oryginalną metodę, polegającą na niesprzeciwianiu się w niczym swoim pacjentom, a nawet sprzyjaniu ich psychozie. Sposób postępowania był uzasadniony, gdyż: „taka «hodowla obłędu» mogła, zdaniem jego, przynieść olbrzymią korzyść, jeśli nie dla danego pacjenta, to przynajmniej dla nauki, wzbogacając nadzwyczajnie psychologię chorób umysłowych" ${ }^{\text {"1 }}$ - dlatego też bardzo starannie notował wszystkie spostrzeżenia i przeżycia swoich pacjentów. Ludzimirski wydaje się zafascynowany światem duchowym zbudowanym na bazie obłędu. Przyglądając się podopiecznym z naukową wnikliwością, stosuje nowoczesne metody, tj. stara się doprowadzić manie do granic ostatecznych, a tym samym dąży do wypalenia niezdrowych skłonności. O słabości, czy może o podatności ludzkiego umysłu na szaleństwo, świadczy choroba najbliższego współpracownika dyrektora, doktora Janczewskiego. Zachorował na „melancholia progressiva” z domieszką tak zwanej idées fixes - stał się maniakiem ognia. Chorobowa wizja Janczewskiego udzieliła się innym pensjonariuszom i w krótkim czasie zamieniła w rodzaj religii z liturgią, kastą kapłańską i arcykapłanem. Ludzimirski, zgodnie z ideą leczenia, nie sprzeciwia się kultowi, wręcz umożliwia chorym założenie bractwa Gebrów, czyli czcicieli ognia. W krótkim czasie terapia doprowadziła do tragedii. Opętani pensjonariusze interpretują kult $\mathrm{w}$ duchu diaboliczno-seksualnym, stają się agresywni, dopuszczają się szeregu zbrodni, by w końcowym akcie spalić się, zbawiając ludzkość. „Z hymnem Dies irae wzniecają pożar i zakład dra Ludzimirskiego kona w szalejących płomieniach obłąkanego autodafé" [TLSG, s. 219].

Grabiński nie poprzestawał jedynie na opisie terapii i jej ewentualnych skutkach, ale też zasłynął jako pisarz wiernie odtwarzający stany chorobowe psychiki. W opowiadaniu Spojrzenie doktor Odonicz, po ciężkich przeżyciach spowodowanych samobójczą śmiercią żony, popada w stany podobne do nerwicy psychastenicznej. Nawiedzają go nieuzasadnione lęki przed czymś, co kryje się poza zasięgiem jego wzroku, doznaje halucynacji.

Utwór ten pod względem prezentacji problemu i statusu ontologicznego opisywanych zdarzeń należy do ciekawszych. Może być odbierany jako niesamowita opowieść realistyczna, gdyż świat przedstawiony budowany jest jako rzeczywistość realna, widziana oczyma obiektywnego narratora, która ulega odrealnieniu pod wpływem postępującej choroby umysłowej. W tym sensie Spojrzenie stanowi precyzyjny pod względem klinicznym obraz psychozy neurastenicznej na tle lękowym. Fantastyczność zanika, gdyż wszelkie zjawiska stają się wytworami jednostkowej psychiki bohatera. Jeśli uznamy jednak, że wszelkie fenomeny są przejawem sił nadnaturalnych, że doszła do głosu prawda metafizyczna, wówczas potraktujemy utwór jako fantastyczny, gdyż zjawiska otrzymają byt realny.

\footnotetext{
${ }^{30}$ Ta reforma przyczyniła się nawet do kilku uzdrowień, a według legendy medycznej jeden z uleczonych uratował Pinelowi życie. Zob.: W. Szumowski, op. cit., s. 635-636.

${ }_{31}$ S. Grabiński, Gebrowie, s. 85. Podobnie postępuje bohater dramatu Manowiec, dr Jan Orsza.
} 
$\mathrm{Z}$ urojeń Odonicza, przedstawionych $\mathrm{w}$ formie monologu wewnętrznego, wynika, że możemy tu mieć do czynienia z solipsyzmem. Teoria George’a Berkeleya, przedstawiciela solipsyzmu relatywnego, głosi, iż istnieć, to być postrzeganym. „W samej rzeczy, przedmiot i wrażenie zmysłowe, jest to jedno i to samo, więc jedno od drugiego oderwanem być nie może"32. Istnieje jedynie podmiot dokonujący postrzeżenia (duch postrzegający), a rzeczywistość, która go otacza, jest jedynie fikcją umysłu, czyli zespołem jego wrażeń zmysłowych. Świat zewnętrzny składa się z jakości postrzeganych, poza którymi nic się nie kryje. Przedmioty istnieją niezależnie od jednostkowych postrzeżeń człowieka, ponieważ istnieje duch - Bóg gwarantujący stałą percepcję, tym samym otwierający drogę do wiedzy opierającej się na stałych fundamentach ${ }^{33}$. Bohater Grabińskiego, w obawie przed śledzącym go „spojrzeniem”, pozbawia mieszkanie mebli oraz wszelkich elementów zdobniczych przesłaniających przestrzeń, jak np. zasłony. Starania te jednak pomogły na krótko, gdyż wkrótce pewne przedmioty zaczęły się pojawiać w miejsce innych. Poczuł się zastraszony i osamotniony, gdyż zaczął rozważać hipotezę, iż nic, poza nim, nie istnieje. „To on tylko wciąż myśli, on, dr Tomasz Odonicz, a wszystko, na co patrzy i co spostrzega, to tylko wytwór jego kontemplacji” (NO, s. 332). Kiedy na koniec zbiera się na odwagę, aby spojrzeć za siebie i potwierdzić bądź odrzucić teorię o prześladowaniu przez tajemnicze siły, umiera na zawał serca. Mimo to czytelnik nie otrzymuje jednoznacznej odpowiedzi co do natury opisywanego $\mathrm{w}$ opowiadaniu zjawiska. Bohatera w równym stopniu mogły zabić emocje, jak i siły spoza realnej rzeczywistości.

W Spojrzeniu ponownie pojawia się kwestia związku umysłu z ciałem i wzajemnego ich oddziaływania. Pozostaje nierozstrzygalne pytanie, czy to umysł rządzi ciałem, czy też choroba ciała powoduje anomalie w mózgu? Jakakolwiek byłaby odpowiedź, to jeden wniosek pozostaje niezmienny: obłęd jest stanem na swój sposób atrakcyjnym. Bohaterowie naznaczeni piętnem choroby umysłowej wkraczają na drogę wtajemniczenia duchowego. To piętno, ale zarazem stygmat wybranych, wyzwolonych spod praw norm i przeciętności. Szaleni bohaterowie Grabińskiego przekraczają kolejne granice wytyczone przez moralność mieszczańskiego społeczeństwa. W opowiadaniu Płomienne gody chemik i wynalazca, Władysław Kobierzycki, doprowadził swoją żonę do obłędu. Otóż główny bohater i narrator zarazem cierpiał na zaburzenia seksualne, polegające na tym, iż odczuwał pożądanie jedynie, kiedy był świadkiem pożaru. Poznał swoją żonę podczas pożaru jej willi. Mimo iż Stanisława znała problem Władysława, zgodziła się wyjść za niego za mąż, a nawet podpaliła sypialnię w noc poślubną, aby się z nim kochać. Jej psychika stopniowo poddawała się obłędowi: „Przychodzily na chorą okresy depresji, gdy całemi dniami siedziała nieruchomo z oczyma wlepionymi w szybę okna, to znów ataki szału [...]. Czasami przeradzał się obłęd w bezdenny strach przed pożarem, w piekielną grozę ognia $[. . .]^{\prime 34}$. Innym razem pragnęła ognia, pożądała go, była nim zafascynowana i zrobiłaby wszystko, aby znaleźć się blisko niego. Zdolna nawet była wywołać pożar. Jej szaleństwo narastało powoli, z początku niezauważalne, z czasem stało się zagrożeniem dla jej bliskich. Władysław, który zrazu sądzil, iż to on odbiega od społecznie przyjętej normy zachowań, zafascynowany i zrozpaczony zarazem,

32 J. Berkeley, Rzecz o zasadach poznania, tłum. F. Jezierski, Warszawa 1890, s. 31 ['1710].

33 Zob. S. T. Kołodziejczyk, Posłowie, [w:] G. Berkeley, Traktat o zasadach ludzkiego poznania, w którym poddano badaniu główne przyczyny błędów i trudności w różnych dziedzinach wiedzy oraz podstawy sceptycyzmu, ateizmu i niewiary, tłum. J. Salamon, Kraków 2004, s. 91-107.

${ }^{34}$ S. Grabiński, Płomienne gody, [w:] idem, Księga ognia, s. 136. 
obserwuje stopniowe popadanie w obłęd swojej żony. Usiłuje dociec, gdzie był początek choroby i czy współczesna medycyna zdoła pomóc pacjentce. Jak w większości opowiadań Grabińskiego, medycyna znów okazuje się bezsilna.

O tym, jak nośny był temat szaleństwa i stopniowego popadania w obłęd, świadczy wypowiedź Stanisława Trzebińskiego z 1907 roku, który analizując współczesną sobie beletrystykę polską, zauważy1, iż bardzo trudno zdefiniować pojęcie „normalności”, „stanu normalnego lub nienormalnego". Stwierdził ponadto, że są to pojęcia względne, „granice zaś przesuwają się $\mathrm{w}$ jedną lub $\mathrm{w}$ drugą stronę, nie tylko zależnie od czasu i przestrzeni, a więc epoki i rasy, lecz także od mniej lub więcej dokładnej znajomości tych osób lub grup społecznych, o których normalności wyrokujemy"35. Szaleństwo może być chorobą, ale również może kryć w sobie początki myśli genialnych. „Pogłębiające się opętanie jedną jedyną myślą, stopniowe pogrążanie się w mroki obłędu, to właściwie powolne wstępowanie w świetlisty krąg jasnowidzenia” (TLSG, s. 216). Należy się więc obłąkanym szacunek i opieka, aby mogli przekraczać granice i dosięgać myślą rejonów innym niedostępnych.

\section{Na straży racjonalizmu - zamiast zakończenia}

Próbując podsumować dotychczasowe rozważania, można powiedzieć, iż $\mathrm{w}$ światach przedstawionych wykreowanych przez Grabińskiego przyczyną wszelkiej choroby są albo przybysze z Innego Świata, albo sam Inny Świat, który poprzez oddziaływanie na umysły wrażliwe doprowadza je do choroby, rozpadu i zerwania z rzeczywistością realną świata przedstawionego. Do ludzi szczególnie predestynowanych do ulegania wpływom mocy z innej rzeczywistości należą niektórzy artyści, lekarze i kolejarze. O ile przynależność do pierwszej grupy jest oczywista ze względu na poglądy głoszone przez ideologów Młodej Polski i powrotu idei artysty pojmowanego jako istoty żyjącej na granicy światów, o tyle lekarz i kolejarz są pewnym novum w tym ujęciu. Pozostając przy postaci lekarza, szczególnie lekarza psychiatry - ujawnia się niepokój związany z profesją obarczoną zaufaniem społecznym, wręcz obowiązkiem bycia „normalnym”, stojącym na straży tej normalności. Pewnym wyjaśnieniem mogą być odmienne niż w innych specjalnościach medycznych obowiązki nakładane na psychiatrę, a zdefiniowane przez Jakuba Frostiga we wstępie Psychjatrii, podręcznika dla studentów z 1933 roku: „Leczenie nerwowo chorych wymaga od niego [lekarza] nie tylko wiadomości lekarskich, ale także i znajomości duszy ludzkiej”36. W twórczości Grabińskiego, choć w dość ograniczonym zakresie, widać przemiany zachodzące we współczesnej mu medycynie, etosie i filozofii tego zawodu. Zadania lekarza zaczęły obejmować, oprócz leczenia i ochrony społeczeństwa przed chorym, zabezpieczenie chorego przed społeczeństwem i jego działaniami. To najistotniejsza zmiana, jaka - wydaje się - na przełomie wieków następuje.

${ }^{35}$ S. Trzebiński, Psychoza i nerwica w beletrystyce polskiej, cz. 3, "Archiwum Historii i Filozofii Medycyny oraz Historii Nauk Przyrodniczych", red. A. Wrzosek, t. 3, z. 2, Poznań 1925, s. 253 ['1907].

${ }^{36}$ J. Frostig, Psychjatria, t. 1, cz. 1, Lwów 1933, s. 9. 
Ambiwalencja w ocenie bohaterów jest dość zastanawiająca. W noweli Gebrowie lekarz zostaje niejako usprawiedliwiony, gdyż wszelkie jego działania spowodowane są działaniem sił wyższych, potężniejszych od niego. Cały porządek rzeczy, wiedza o tym, co normalne, i o tym, co nienormalne, zostaje zburzona i poświęcona na ołtarzu, w sensie dosłownym i metaforycznym, Wielkiej Tajemnicy. Z kolei doktor Toczyński w Cieniu Bafometa usiłuje pomóc bohaterce poprzez seans spirytystyczny, lecz jedynie doprowadza do samobójczej śmierci pacjentki. W tej samej powieści inny bohater, Szantyr, traci nie tylko zdrowie przez długoletnie eksperymenty hipnotyzera i lekarza, dra Józefa Wokierda, lecz również dobre imię. Pod wplywem hipnozy Szantyr dopuszcza się haniebnego czynu. W innych opowiadaniach lekarze starają się, z różnym skutkiem, pomóc swoim podopiecznym. Społeczność lekarska nie została tu poddana specjalnej krytyce, lecz raczej próbie obiektywnej oceny. Pisarz wykazał, że również w tej grupie zawodowej pojawiają się altruiści i oszuści, a nawet hochsztaplerzy.

Część nowel świadczy o wspomnianej już specjalnej wrażliwości, charakteryzującej synów Asklepiosa. Grabiński, czyniąc w niektórych opowiadaniach narratorem i bohaterem lekarza, odtwarza próby naukowego poznania niesamowitych zjawisk. Proces stopniowego opętania własnymi myślami, przeżywania emocji z niezwykłą intensywnością pisarz przedstawia „Z wręcz naukowym obiektywizmem i prowadzi do rozwiązania z konsekwencją matematycznie logiczną”. W utworach Grabińskiego wszystko jest logicznie uzasadnione, a zjawiska niesamowite „wyrastają ze świata zjawisk najzupełniej rzeczywistych”37. Konflikt wynika ze względności postrzegania przez daną osobę rzeczywistości i rzutowania własnych stanów na otoczenie.

W utworach Grabińskiego lekarze „od ciała” potraktowani zostali jak wyrobnicy bądź rzemieślnicy. Pojawiają się wraz ze śmiercią tylko po to, aby ją zaanonsować. Nikogo nie leczą, nie są w stanie nikomu pomóc, pomijając utwory z opisem katastrof kolejowych i pożarów, kiedy zjawiają się jako anonimowa pomoc dla poszkodowanych. Bezsilni wobec nieznanego, bronią swój umysł przed dopuszczeniem myśli o innych, nierzeczywistych światach. Realizują starannie budowany przez cały XIX wiek etos lekarza racjonalisty. Wymóg bycia strażnikiem racjonalizmu i przedstawicielem myślenia zdroworozsądkowego stawiany był przez rodzinę pacjenta, czasem samego chorego. Czymże jednak jest ów racjonalizm? Psychologia pozostała bezradna, wskazując, jak niewiele dzieli umysł chory od zdrowego, panikę od stanu spokoju. Granice nie zawsze są łatwe do wskazania, a stopień zaawansowania choroby, czy też określenia stanów granicznych, również podlega różnym kwantyfikatorom. Jednym z wyznaczników „normalności” są działania racjonalne. Trudno wyobrazić sobie pojęcia, dyskursy, które nie angażowałyby tego pojęcia, będącego wartością autonomiczną w naszej cywilizacji. Filozofowie, starając się uniknąć nieporozumień i nieustannie zmagając się z doprecyzowaniem pojęcia, zamiast definicji często wymieniają typy racjonalności. Streszczając różne poglądy, można powiedzieć, że problem „racjonalności” opisuje się na trzy sposoby. Po pierwsze, „racjonalność bywa określana przez wymienienie szczegółowych reguł metodologicznych, które muszą spełnić (hipotezy, zdania, metody) "38. W drugim ujęciu podkreśla się, że wiedza racjonalna równa jest wiedzy metodycznie zdobytej, „sformułowana w języku intersubiektywnie zrozumiałym, logicznie usystematyzowana, uzasadniona w sposób intersubiektywnie kontrolowany, wolna od stanów emocjo-

\footnotetext{
37 K. Czachowski, op. cit., s. 540, 541.

${ }^{38}$ M. Tałasiewicz, O pojęciu „,racjonalności”, cz. 1, „Filozofia Nauki” 1995, nr 1/2, s. 81-92.
} 


\section{Ludwik Bernacki}

(1882-1939), z ramienia

Ossolineum, którego był długoletnim dyrektorem,

został członkiem jury

przyznającego pisarzowi nagrodę literacką miasta

Lwowa. Ze zbiorów Biblioteki

Ossolineum

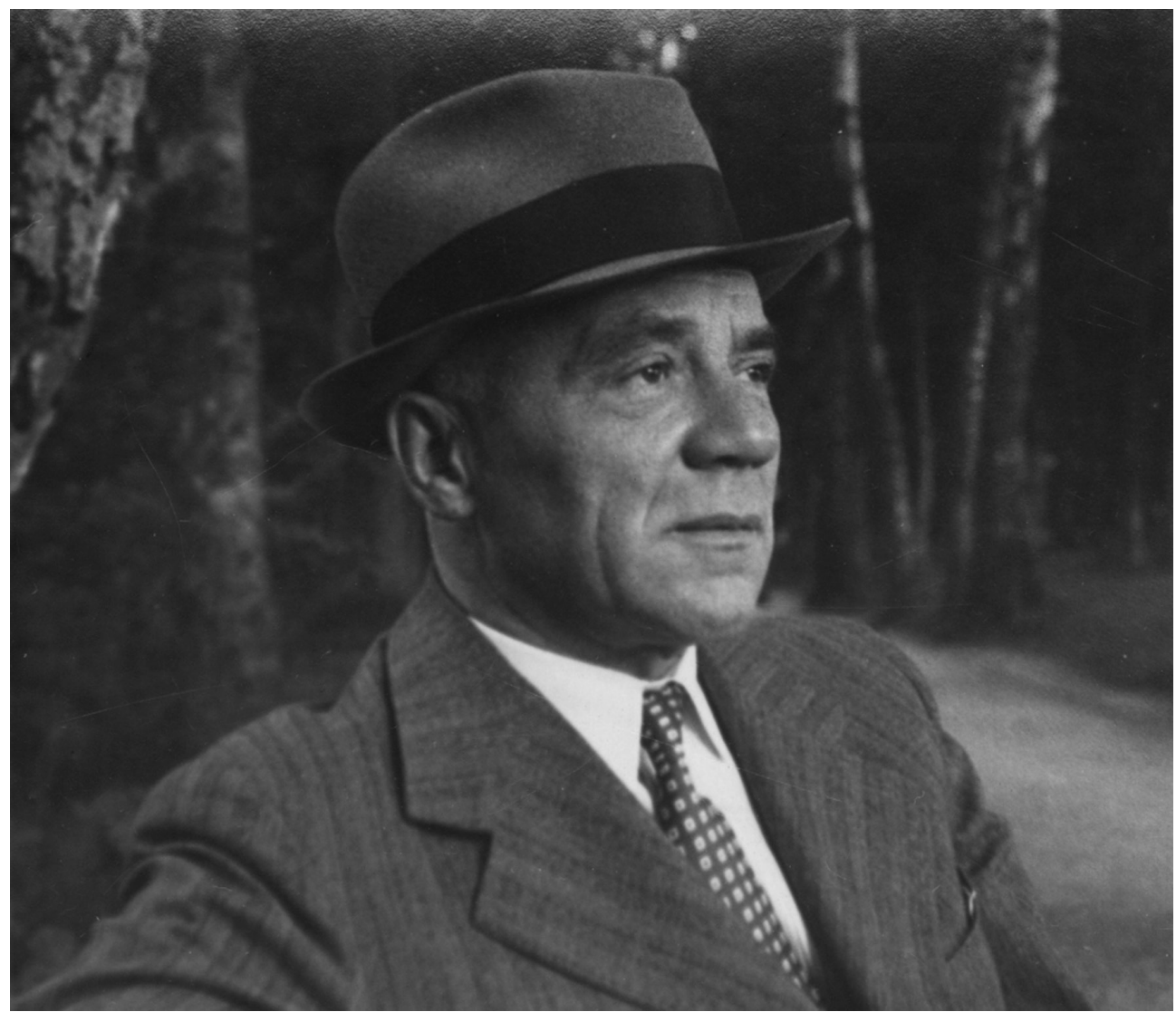

nalno-wolitywnych" ${ }^{39}$. Trzeci sposób mówienia o racjonalności odwołuje się do zgodności $\mathrm{z}$ rozumem ${ }^{40}$. Podstawowym kryterium, choć nie jedynym, orzekania o racjonalności jest kryterium przedmiotu. „Racjonalność orzekamy bowiem o myśleniu, działaniu bądź też o bycie w ogóle" ${ }^{\prime 1}$. W wypadku stanu umysłu orzekającym jest lekarz, i to na nim spoczywa pełna odpowiedzialność oceny stopnia zdrowia bądź choroby. Grabiński wykazal, jak złudna może być ta ocena, jak niekompetentna. Co ciekawe, do pewnego stopnia usprawiedliwia ona, właśnie przez wpływ złych sil, ów chorobotwórczy kontakt z innym światem. Być może dlatego jedynymi lekarzami godnymi uwagi są lekarze umysłu - psychiatrzy lub spirytyści, uwrażliwieni na „drugą stronę”. Podatni na wplywy innego świata prezentują postawę niemocy, bezsiły wobec potęg, które nawet jeśli rozumieją, to nie mogą się im przeciwstawićt ${ }^{2}$. Godni artystów, widzący poza rzeczywistością ludzi przeciętnych, pozostają jednak racjonalistami we własnym tego słowa rozumieniu. Oni nie wierzą, lecz wiedzą, co zmienia status ontologiczny ich dowodzenia i rozumienia choroby, i odróżniania stanu nie-

39 Ibidem, s. 93-94.

40 Ibidem, s. 95.

41 R. Kleszcz, O racjonalności. Studium epistemologiczno-metodologiczne, Łódź 1998, s. 85.

42 Zob. M. Adamiec, „Cień wielkiej tajemnicy”. Rzecz o opowieściach Stefana Grabińskiego, [w:] idem, „Cień wielkiej tajemnicy..." Norwid, Grabiński, Leśmian, Tyrmand, Mackiewicz, Herbert, Vincenz..., Gdańsk 1995, s. 69-91. 
normalnego od normalnego. Pojawia się więc problemat sensu leczenia psychiatrycznego, skoro ci, którzy nie wiedzą, nie są w stanie rozpoznać i wyleczyć choroby przez anihilację źródła, a ci, którzy wiedzą, nie mają dość siły ani umiejętności na walkę. Bohater lekarz nie wyrzekł się jeszcze wiary w potęgę rozumu, zachował niemałą dozę sceptycyzmu, a jednocześnie zajmuje się studiowaniem horoskopów, lektur z zakresu mistyki i parapsychologii. Naukowy światopogląd przestaje wystarczać, a istnienia odmiennych rzeczywistości już się nie neguje $e^{43}$. Zastosowana $\mathrm{w}$ utworach fantastyczność, dzięki której byty $\mathrm{z}$ innego świata nabrały realizmu i przeszły ze sfery imaginacji w sferę bezpośredniego poznania, pozwoliła na wyeksponowanie problemów i wyjaskrawienie postaw bohaterów.

Niewątpliwie w tekstach Grabińskiego można odnaleźć sygnały świadczące o dyskusjach dotyczących ludzi medycyny, toczących się za jego życia. Te spory, często mające charakter burzliwy, dotyczyły wszelkich sfer profesji lekarza - od umiejętności zawodowych po deontologię. Analizując wybrane opowiadania pisarza, łatwo zauważyć, iż w niewielkim stopniu występuje w nich problematyka związana bezpośrednio z medycyną. Jednak sama ich obecność predestynuje do wysnucia wniosków. W tym ujęciu wizerunek lekarza u Grabińskiego świadczy o zachodzących przemianach cywilizacyjnych i wydaje się, że nie jest to jedynie wynik jego choroby. Narodziny współczesnej służby zdrowia, nowych instytucji związanych z medycyną - od przychodni po szpitale i specjalistyczne laboratoria - nie skłaniają pisarza do pozytywnej oceny. Widać tu niepokój związany ze zjawiskiem medycyny klinicznej, zinstytucjonalizowaniem samej choroby, odpersonalizowaniem pacjenta i kształtowaniem się nowoczesnego środowiska lekarskiego. W utworach Grabińskiego uderza bezradność medycyny zarówno wobec wypadków losowych, jak i różnorodnych schorzeń o nieznanej etiologii.

Choć artykuł ten stanowi zaledwie przyczynek dla szerszych badań, to można powiedzieć, że opisane odczucia wobec medycyny, jej osiągnięć i ludzi ją reprezentujących charakterystyczne są nie tylko dla pisarza, ale również dla jego czytelników. Fikcyjne światy wyrastają z szerszego kontekstu kulturowego, wspólnego dla określonej społeczności w danym czasie. Dlatego znaczenie ma reprezentatywność, przedstawianie stereotypowych przedmiotów i zjawisk, a umiejętność ich odczytania pozwala na pełniejszą rekonstrukcję świadomości społecznej w konkretnej czasoprzestrzeni ${ }^{44}$. Pokazywanie zaś przedstawianych w utworach odstępstw od normy przyczynia się do poznawania granic kultury. Dzieło literackie widziane jest tu jako realizacja, aktualizacja i konkretyzacja danego wzorca, w tym wypadku - medycyny. Znajomość klucza, umożliwiającego odczytanie tego wzorca, pozwala lepiej poznać ludzką naturę i warunki życia konkretnej społeczności.

${ }^{43}$ Na przełomie wieków powstaje szereg uczonych dysertacji udowadniających istnienie innych światów. Zob. L. Chwistek, Wielość rzeczywistości, Kraków 1921.

${ }^{44}$ Zob. L. Villoro, O sensie istnienia historii, [w:] Po co nam historia?, tłum. M. Mróz, Warszawa 1986, s. 41. 